\title{
The Azanian Philosophical Tradition Today
}

Even though the Pan Africanist Congress was formed in 1959 after departing from the African National Congress at a point marking out the irreconcilability of the Azanian 'faith' with the other interpretations of the struggle within the 'broad church' of the Congress Movement, it was only six years later, in 1965, that it modified its name to the PAC of Azania. The name Azania is supposed to have been suggested by Nkrumah at the All-African Peoples' Conference in 1958 attended by the Africanists even before the inauguration of the PAC (Diaz 2009: 239; Hilton 1993: 5). The Azanian tendency in 'South African' history can arguably be said to have existed from the earliest times of resistance by the indigenous people against the unjust wars of colonisation (see Dladla 2020: 71-108).

It appears as a political tendency which can be traced throughout the history of 'South Africa' characterised by a principle ethical and political refusal to accommodate the new colonial reality. Some political historians have described it as 'rebellious' in a literature in which they counter-pose it to 'realist' (Gerhart 1978: 40-44). According to this view, the 'realists' moving from the basis of the experience that Africans had already been conquered by a more powerful group than themselves saw the best way to approach the question of liberation - the realistic way - as gradual and accommodationist. They sought to appeal to the conscience of their oppressors and seek assistance from the more liberally minded within the ranks of their oppressors. To use the existing structures set up by the conqueror's regime and even methods prescribed by the conqueror to agitate for rights and freedoms within the conquered territory. They always approached their goals careful not to offend their oppressors. The rebels, on the other hand, proceeding from the established unethical nature of the prevailing situation, had no 
patience for it and pursued a variety of approaches aimed at wholesale revolution rather than reform. Gerhart, for example, writes:

The realist regarded the possibility of violent revolution with apprehension, the rebel lived for the day of confrontation. The difference in their outlooks was, most fundamentally, a temperamental one. Where the realist looked primarily to past experience as a guide for action, the rebel's inclinations were more intellectual and theoretical. Where politics was the art of the possible for the realist, the rebel saw politics as a matter of bed-rock principles, as something linked to his own personal search for integrity and identity. (1978: 43)

We would agree with Gerhart's characterisation only with the proviso that, for the Azanian tradition, revolution's purpose is not violence but peace. Azanians move from the reality that what is characterised as peace is really the 'conqueror's peace'. To date, South Africa's transition is called peaceful and sometimes even described with the theological prefix 'miraculous'. Yet South Africa has a famously high murder rate which overwhelmingly affects the indigenous people conquered in the unjust wars of colonisation. These murders, far from arising from apolitical sources, are a direct result of the compromise of the early 1990s that has left the indigenous peoples conquered in the unjust wars of colonisation living in the squalor of the townships Biko had in the 1970s described surviving to adulthood within using the same adjective: miraculous. However, dwelling upon the political theory of 'crime' is outside of the scope of this special issue. We only wish to establish that the purpose of revolution for the Azanians is the establishment of just peace since their understanding of what prevails now in contemporary South Africa is understood as it was in the late 1950s when the PAC was formed as an ongoing unjust war.

The PAC itself was formed by a group of freedom-minded 'rebels' who saw the ANC as having truly surrendered their will for an unencumbered and total freedom. According to the PAC, the ANC had surrendered its will to freedom by accommodating the prevailing and unethical colonial reality demanding ${ }^{1}$ the declaration that 'South Africa belonged to all who lived in it, black and white'. For the PAC formed at that time, the ANC surrender dismembered it from the quest for the liberation of 'South Africa' and Africa at large. On this basis, the 'rebels' set out to create a new political 
vehicle, the Pan Africanist Congress, to carry out the struggle for liberation.

The PAC, referred to here as the Azanians, insisted that the struggle for liberation, understood as the restoration of unencumbered sovereign title to territory, predated the advent of European-educated African intellectuals and their political parties. Instead, they saw themselves and their organisations as merely contemporary iterations in an already thitherto multi-century war of resistance against colonial conquest. They counted the great kings and their warriors, figures such as the brother Kings Shaka and Dingane ka Senzangakhona, Ikumkani uHinsta ka Khawuta, Kgosi Sekhukhune, Kgosi Mampuru, Khosi Moshoeshoe, and the great warrior Inkosi uBhambatha kaMncinza as forbears in their approach to the struggle for liberation.

In the PAC's understanding, the restoration of unencumbered sovereign title to territory to the indigenous people conquered in the unjust wars of colonisation was an ethical exigency necessitating the colonial conqueror's renunciation of sovereignty over 'South Africa'. Such renunciation must answer to the dual exigency of economic [material] and epistemic justice. This end-result would be the establishment of Azania and the death of conqueror South Africa. Azania was to be a wholly African polity rather than the old colonial vision of a piece of Europe in Africa. ${ }^{2}$ It was to be a different idea of nationhood, of law and justice, national culture, values, and democracy (Delport 2016). Both the use of the name Azania and a minimum ideological outline were to spread beyond the confines of the PAC into the various organisations of the Black Consciousness Movement. Azania may thus be understood as the ends to which Africanist and Black Consciousness ideology and liberation philosophy were aimed. It is necessary, therefore, to discuss some basic tenets of this understanding of and approach to the struggle for liberation.

The most important features relevant to the present elaboration are as follows:

1. The demand by Azanians that the objective of the liberation struggle was, and still is, the recovery of unencumbered sovereign title to territory complemented by the attainment of civil and political rights. To some, the current 1996 constitution 
of conqueror South Africa answers to the demand for civil and political rights. For the Azanians, however, the answer is incomplete because it is given without corresponding economic emancipation, thus intensifying the bondage of ethically unjustifiable debt on the indigenous peoples conquered in the unjust wars of colonisation. Epistemic freedom is a necessary complement to this.

2. The insistence that the title to territory itself belongs exclusively to the indigenous peoples conquered in the unjust wars of colonisation.

3. The rejection of multi-racialism. This includes incredulity to the tenability of what we discuss elsewhere as 'non-racialism as a means' and upholding it only as an end achievable only once the title to territory had been restored to the indigenous conquered peoples (Dladla 2017).

4. The recognition of 'South Africa' as a polity and idea inextricably bound to the imagination, will, and interests of the conqueror, that is, conqueror South Africa, an ethically untenable reality, demanding state succession by a liberated polity.

5. This yet-to-be-born Azanian polity would then become an equal and full member of the community of African states. This is against the background of the political history of 'South Africa' having constructed its identity as distinctly European and bearing no cultural resemblance and relationship with 'the rest of the continent'.

6. Vigilant awareness that the quest for Azania shall have consequences for world politics.

By the Azanian Philosophical Tradition we mean to describe the contemporary theoretical and praxiological activity that has its foundation in the historical activities ${ }^{3}$ and thinking of the previously mentioned political organisations. It includes a sustained study of the work of intellectuals who continued to write after 1994, some in the academy and others outside of it. ${ }^{4}$ Although these figures are not all academic philosophers, it is the principles upon which their work is predicated that are instrumentalised and developed in Azanian critical philosophy.

The Azanian Philosophical Tradition is part of the discourses on post-colonial African philosophy. ${ }^{5}$ This approach to philosophy is 
one that originates in the experience of the struggle against colonial (and then neo-colonial) domination in Africa. Historically, many of its central theoreticians were gifted African intellectuals, educated in various fields, sometimes in Western academic philosophy itself, for example, Kwame Nkrumah and Lembede. Few of them were, however, simply academics. They were soldiers, activists, organisers, lawyers, and freedom fighters who distilled their thought in the process of the engagement of struggle. With a few exceptions, such as Nkrumah, many of their works are not written as extended treatises in the fashion of academic philosophy. Instead, they survive as pamphlets, speeches, letters, and notes that are nevertheless rich sources of social, legal, economic, and political philosophies as well as epistemology, metaphysics, and ethics. Sobukwe's writing on Africanism, Léopold Senghor's on Negritude, Julius Nyerere's on Ujamaa, Kenneth Kaunda's on African 'humanism', and Bantubonke Biko's writings on Black Consciousness philosophy come to mind as examples in this regard, not forgetting the poetry and writings of physician-presidents Agostinho Neto and Félix Houphouët-Boigny. Henry Oruka, describing the character of nationalistic-ideological African philosophy writes that: 'It is clear that this philosophy is claimed to be rooted in the traditional or communal Africa, but it is explicit that it is actually a philosophy of the individual author concerned. Thirdly, this philosophy is practical and has explicit problems to solve, namely those of national and individual freedom' (Oruka 2002:122).

Azanian philosophy then also meets the minimum criteria set by Mogobe Ramose, Tsenay Serequeberhan, and Theophilus Okere, among others, for the practice of African philosophy, namely, that it has its basis upon 'the culture and experience of African peoples' and the 'African philosophy would at the very minimum be arguing for the liberation of African philosophy from the yoke of dominance and enslavement under the European (Western) epistemological paradigm' (Ramose 1999: 37).

The articles contained in this issue cover a wide array of disciplines spanning from archaeology, history, intellectual historiography, geography, aesthetics, political philosophy, and jurisprudence. They are united in a broad sense through their reflection upon the contemporary reality of Africa today from a theoretical foundation which takes the ongoing unfreedom of its indigenous conquered 
people and the necessity of its complete repudiation as its starting point. Taking this as the starting point of this perspective, various questions arise for both our imagination of the past and future and have implications for various dimension of social and political reality. Although the articles in this issue cover a wide array of these implications, it is by no means an exhaustive expression of either the historical and theoretical foundations of the Azanian Philosophical Tradition or the totality of its implications for our interpretation of social and political reality. The issue may be taken as a small gesture in the foundation of a dialogue about an important dimension of South Africa's intellectual and political history and the implications it has for the ongoing struggle for the liberation of the indigenous peoples and conquered in the unjust wars of colonisation and indeed all human beings.

Felix Chami, whose article opens this special issue, is an archaeologist specialising in the territorial sites of ancient Azania who comes from one of its contemporary successors in title Tanzania. His masterly work The Unity of Ancient Black Africa 3000BC to $A D 500$, among other things, addressed the methodological consequences of racism in the study of Africa's past. There he shows the stubbornness of the Hamitic myth which has seen scientists ignoring entire bodies of material evidence when studying Africa's past in favour of groundless theories which sustain the systematic doubt about whether or not Black people are responsible for Africa's ancient civilisations. The history of ancient Azania, as he shows, is no different. Whereas no one has doubted the actual existence of Azania because of its wide recording in ancient geographical and historical texts, the majority of the imperial archaeologists have insisted without evidence that it was not a Bantu polity. He deals with this extensively in his book using historical linguistic and archaeological evidence. In his contribution here, which opens this special issue, he moves beyond his previous work which established that Azania was indeed a Bantu achievement and considers the geographical extent of ancient Azania and the question about whether there is a sound scientific basis to refer to today's Southern Africa as Azania in light of the contemporary efforts towards a Southern African Development Community.

Chami is followed by Tsenay Serequeberhan, a senior statesman of African political philosophy, who hails from an ancient 
neighbour of ancient Azania, modern-day Eritrea. His work over the past four decades has established the philosophical importance of African political organisations and their struggles for liberation as sources in their own right of contemporary African philosophy in ways which have influenced contemporary Azanian theoretical efforts. Here he considers the task of African philosophy today in the context of our unrealised struggles for liberation. He argues that the struggle for liberation must continue not only politically and economically but theoretically as well.

Serequeberhan's article is followed by Joel Modiri's article, 'Azanian Political Thought and the Undoing of South African Knowledges', in which he considers systematically the historical and theoretical foundations of the philosophical tradition and their implications for conqueror South Africa and knowledge generated out of it today. In the article following this, 'For Us, By Us: Towards a More Just Philosophical Community’, philosopher Bryan Mukandi - who hails from the ancient regions of Azania, what is now Zimbabwe - argues for philosophical justice in the context of discursive struggles within a white settler colony not entirely unlike conqueror South Africa. Through a comparative examination of some of the critical insights exposed by the Azanian critique of South African philosophy, his article demonstrates the potential international relevance and contribution of the Azanian Philosophical Tradition to a potential tradition of world philosophy.

Mukandi's article is followed by Anjuli Webster's critical reflections upon the history and theoretical foundations from the perspective of an Azanian philosophy of social sciences: 'South African Social Science and the Azanian Philosophical Tradition'. Tracking the fundamental ethical tensions between conqueror South African social sciences and the silenced but ever-present Azanian critique, Webster dis-covers the deafeningly silenced scandal of colonial conquest which makes up the foundations of the pretensions to scientificity and neutrality throughout the history of what emerge in her critique as settler sciences of social, political, and economic domination.

The penultimate article is Terblanche Delport's 'Erasing the Nation: The Historiography of African Nationalism in Conqueror South Africa'. In this article, Delport provides an assessment of the white historiography writing of the Azanian political tradition. He 
critically addresses various forms of epistemic mischief which seek to silence and disfigure the meaning and significance of the Azanian tradition through the historiographical weaponisation of what Charles Mills (2007) referred to as 'White Ignorance' through the dexterous whispers which have been quietly asserting the right of conquest in some of the most important political historical writing.

Finally, Azanaian historian and philosopher and critic of art, Athi Mongezeleli Joja - who has been experimentally constructing an Azanian reading of contemporary South African art over the past decade - enters the domain of a speculative Azanian aesthetics through his contemplation of the work of the PAC leader and sculptor Jafta Masemola's life and work. His contemplation of the meaning of the Azanian tradition for aesthetics through a close reading of Masemola's master's key leads to a set of propositions in which beauty is inextricably bound to the struggle for the liberation of the indigenous conquered people.

Ndumiso Dladla Guest Editor

\section{Acknowledgements}

A word of thanks to the editors of Theoria for welcoming us into the pages of their immensely important journal in the field of contemporary critical theory in South Africa and to Dr Sherran Clarence for her patience and support during these difficult times where the meaning of time and work have been challenged in so many ways and presented a barrage of unfamiliar challenges. Massive gratitude also to the peer reviewers of the articles for their thorough and thoughtful critical reviews which were responsible for many considerable improvements of the contained texts. Finally, many thanks to our ancestors and teachers in the tradition whose lives and work of struggle for our collective liberation are the possibility condition for the special issue; in this regard, the names of Cheikh Anta Diop, Mangaliso Sobukwe, Bantubonke Biko Cedric Robinson, Oyeronke Oyewumi, Mogobe Ramose, Tiffany WilloughbyHerard, Oshadi Mangena, Malesela Lebelo, and Molora Mabeba must be mentioned. 


\section{Notes}

1. The declaration was indeed a demand. If it were not a demand, why is it that the logic of 'all' is deliberately attenuated by reducing it to 'some' through the silence of the 'Coloured' and 'Indian' population groups who were, ironically, represented and thus present at the declaration that 'South Africa belongs to all who live in it, black and white'. It is a mere shameful afterthought for the ANC to argue that the concept of 'black' at that time meant precisely what it meant thirteen years later under the auspices of the Black Consciousness philosophy. This distortion of conceptual history is scientifically unacceptable. The Freedom Charter presented many problems, however, the most fundamental one was the sleight of hand in terms of which the colonial conqueror's disseizing of territory from the conquered people was suddenly legitimised and turned into a legitimate objective of the liberation struggle. The question which arose was, 'how did South Africa come to belong to the white man'? In terms of the philosophy of the indigenous conquered people, this would have been untenable and needing remedy.

2. L. E. Neame, White Man's Africa: The Problem of a White Nation in a Black Continent, 1952; J. C. Smuts, Africa and Some World Problems, 1930; and C. J. F. Muller, 500Years - A History of South Africa, 1969, all conceive of 'South Africa' as a white man's country, an African province of Europe. This is the status of 'South Africa' to date. It is not, for example, unheard of in 'South Africa' to refer to visiting another African country as having visited 'Africa' or to refer to Africans from beyond the Limpopo as 'Africans' to differentiate them from 'South Africans', even of the indigenous variety. Other dimensions of this illusion include the continued use of terms such as 'African restaurants' and 'African attire' (which is no synonym for 'local' in 'South Africa') to refer to the cuisine and fashion of the indigenous conquered people. The specification is, of course, a marker of alterity, distinguishing whatever is specified from the 'South African' variety.

3. The inclusion of practice here is to make the point that ethical and intellectual activity finds expression beyond the facility of writing. These practices include the very choice by some of our elders to leave the cosy conditions of universities in Europe and America and come back home to teach in 'South Africa', where some continue to be marginalised for political reasons. The refusals to participate in the activities in which the freedom of Africans was sacrificed for comfort in the 'new' South Africa form part of a historical record from which we are able to study both theoretical and practical ethics as well as social and political theory.

4. Motsoko Pheko of the PAC has been an active voice during the entire post-1994 period. His work has included making connections between the constitutional compromise and the 'Freedom Cheater', as he calls it, as well as repeatedly insisting that there can be no talk of liberation without land. Other figures include South African Students' Organisation (SASO) member, AZAPO founding member, and Black Consciousness labour organiser Mandla Seloane, who works as an independent researcher and publisher; and former SASO activist and exile, philosophy professor Mogobe Ramose. Others include historian and founding member of the South African Youth Revolutionary Council Malesela Steve Lebelo and mathematician and community teacher Molora Mabeba.

5. The election of the term post-colonial rather than the oft-used 'decolonial' has an ethical as well as an intellectual basis. In this choice, we follow our esteemed elders, for example, E.C. Eze, Postcolonial African Philosophy: A Critical Reader, 1997, or T. Serequeberhan who writes of 'Philosophy and Post-Colonial Africa' in E.C. Eze, African Philosophy: An Anthology, 1998, pp. 9-22. The point, really, is that Africans are no strangers to colonial conquest or thinking and acting against 
it. The justification for the use of the term 'decoloniality' by its proponents (see R. Grosfoguel, 'The Epistemic Decolonial Turn', Cultural Studies 21, 2007, p. 21 ) is the straw man claim that post-colonial theory is based on the questionable assumption that colonialism is totally over. The decolonialists recognise the residue of colonialism in the forms of the 'coloniality of being, knowledge and power' and, indeed, focus upon both the epistemological and economic (material) issues arising from there. But this is begging the question whether or not the original colonisation is over; a past experience residing in the remotest past of history. One of the burdens of 'decoloniality' or 'post-colonial theory' is its apparent inability to divest itself from Western epistemological captivity while maintaining a critical transformative dialogue with it. That Eurocentricity is a critical problem or that colonialism remained in former colonies in more insidious forms after the formal end of colonial administration was not news to us in Africa. Numerous anti-colonial theoreticians dedicated serious study precisely to these residual phenomena. Kwame Nkrumah's Neo-colonialism: The Last Stage of Imperialism, 1965 is just one example. There is no reason why we should adopt the now in vogue decoloniality/coloniality and ignore our heritage. Whereas we are quite open and willing to learn from the struggles and thinking of other peoples, such as the Latin American intellectuals who have been theorising under the banner of decoloniality theory since the mid-2000s, our exercise is firmly grounded in the African experience and the theoretical and practical resources it has generated since the advent of colonialism.

\section{References}

Delport, T. 2016. 'Asazi ukuthi iyozala nkomoni: Robert Mangaliso Sobukwe's Historical Imagination of the Future', Psychology in Society 50: 35-52. doi: 10.17159/2309-8708/2016/n50a3

Diaz, R. G. 2009. 'Azanism: A Critical Analysis of the Mytho-Reality Complexity of the Azanian Nation'. PhD diss., University of Hamburg. https://ediss.sub.uni-hamburg.de/handle/ediss/3144

Dladla, N. 2017. 'Contested Memory: Retrieving the Africanist (Liberatory) Conception of Non-Racialism'. Theoria 64 (153): 101-127.

Dladla, N. 2020. Here Is a Table: A Philosophical Essay on History and Racel ism. Stellenbosch: African Sun Media.

Eze, E. C. 1997. Postcolonial African Philosophy: A Critical Reader. Hoboken, NJ: Wiley-Blackwell.

Gerhart, G. 1978. Black Power in South Africa: The Evolution of an Ideology. Berkeley: University of California Press.

Grosfoguel, R. 2007. 'The Epistemic Decolonial Turn: Beyond PoliticalEconomy Paradigms', Cultural Studies 21 (2-3): 211-223. doi: 10.1080/09502380601162514

Hilton, J. L. 1993. 'The Peoples of Azania', Scholia ns 2: 3-16.

Mills, C. 2007. 'White Ignorance'. In S. Sullivan and N. Tuana (eds), Race and the Epistemologies of Ignorance. Albany: State University of New York Press. 
Muller, C. J. F. 1969. 500 Years - A History of South Africa. Pretoria: Academica.

Neame, L. E. 1952. White Man's Africa: The Problem of a White Nation in a Black Continent. Cape Town: Stewart.

Nkrumah, K. 1965. Neo-colonialism: The Last Stage of Imperialism. Bedford, UK: Panaf Books.

Oruka, H. O. 2002. 'Four Trends in Current African Philosophy'. In P. H. Coetzee and A. P. J. Roux (eds), The African Philosophy Reader: a text with readings. 2nd ed. Cape Town: Oxford University Press, 120-124.

Ramose, M. B. 1999. African Philosophy Through Ubuntu. Harare: Mond Books.

Serequeberhan, T. 1998. 'Philosophy and Post-Colonial Africa'. In E. C. Eze (ed), African Philosophy: An Anthology. Malden, MA: Wiley-Blackwell.

Smuts, J. C. 1930. Africa and Some World Problems. Oxford: Clarendon Press. 